\title{
Zombie ants, mummified seals and a gorilla punch
}

February's sharpest science shots, selected by Nature's art team.

Daniel Cressey

05 March 2015 । Corrected: 06 March 2015

Deep-sea anglerfish, netted birds and the far side of the Moon are among Nature's picture choice for February 2015.

\section{Trappings of science}
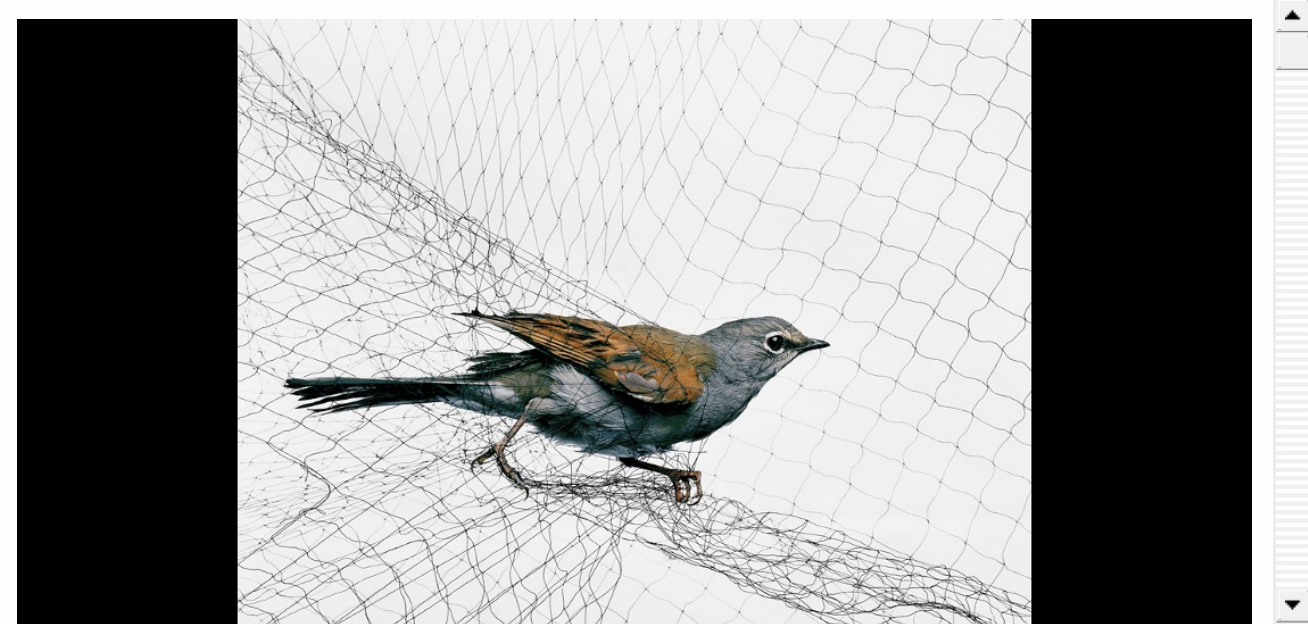

\section{Disappearing smile}

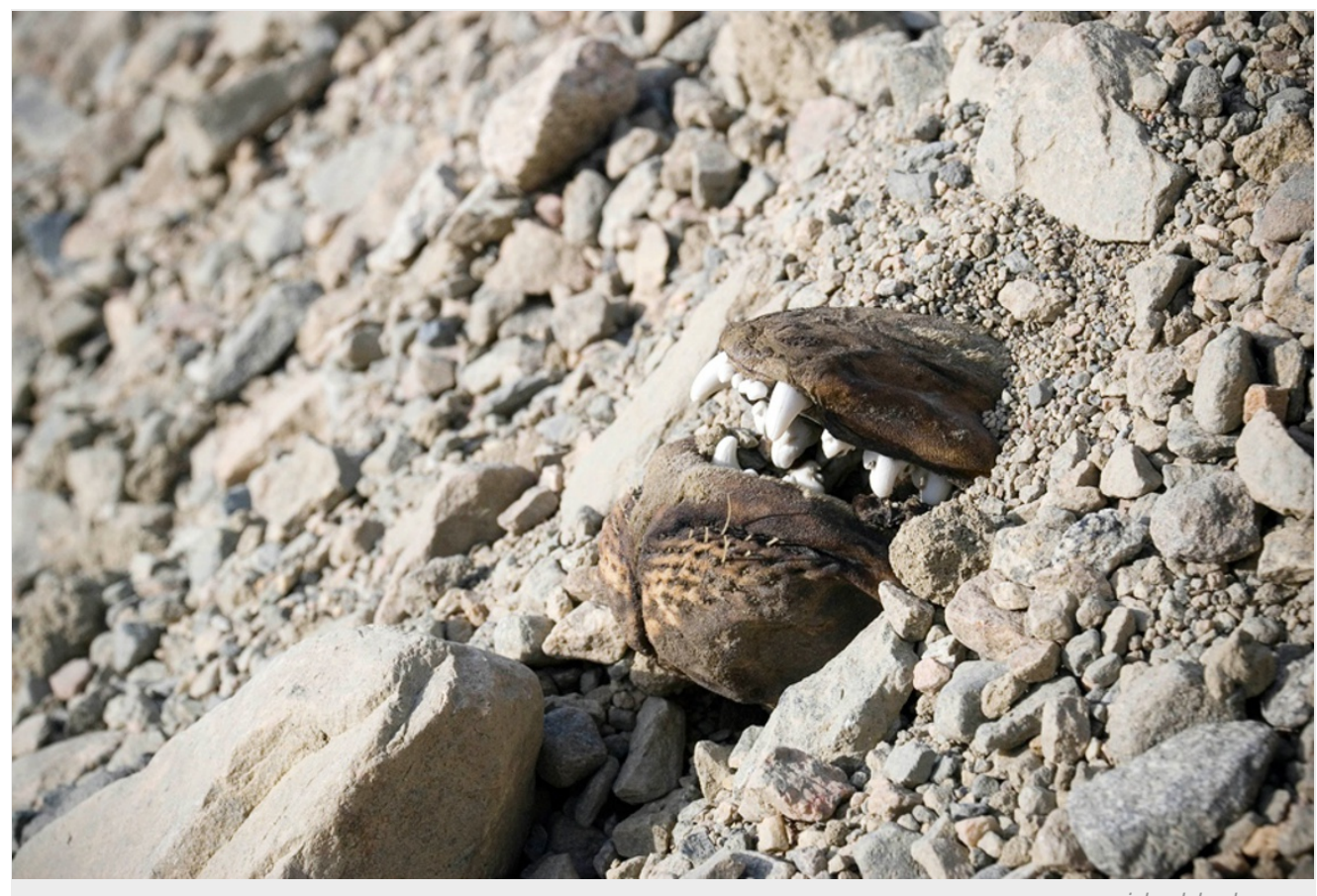

Lost in the McMurdo Dry Valleys of Antarctica, kilometres from the sea, seals have no hope of survival. But when they perish their bodies can become mummified by the arid conditions. Photographer Michael Becker captured this image of one unfortunate mummified pinniped being buried by a glacier. By now, even these shiny teeth may have vanished under the cold ground. 

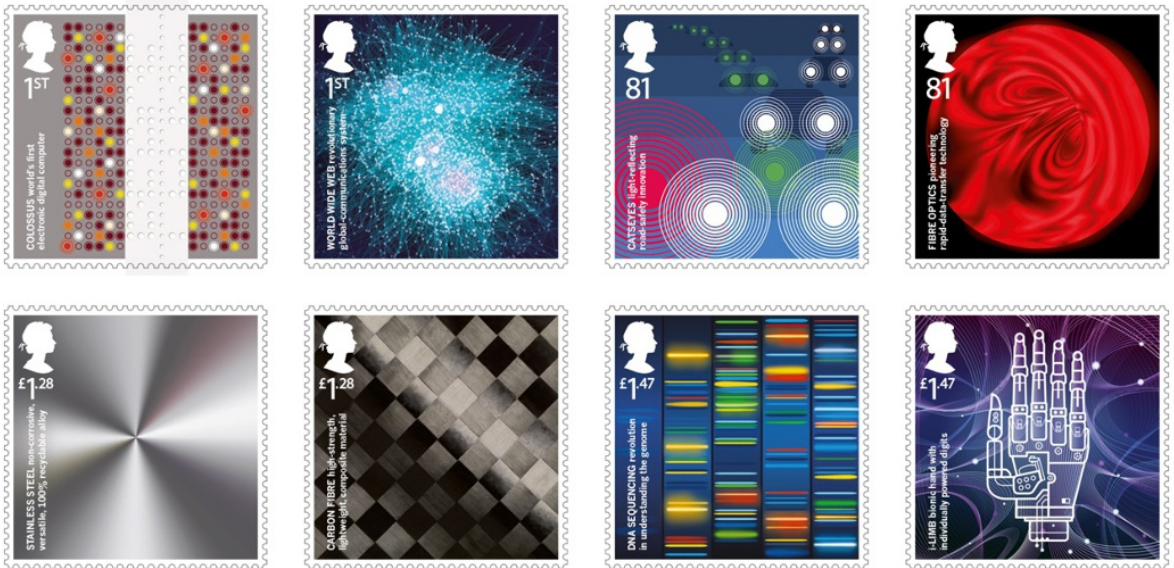

Royal Mail

The Royal Mail, the UK postal senice, has issued a series of delightful stamps that celebrate 'Inventive Britain'. Among the eight inventions highlighted: the Colossus computer from the Second World War codebreaking site Bletchley Park; stainless steel; carbon fibre; and DNA sequencing.

\section{Chemical cloud}

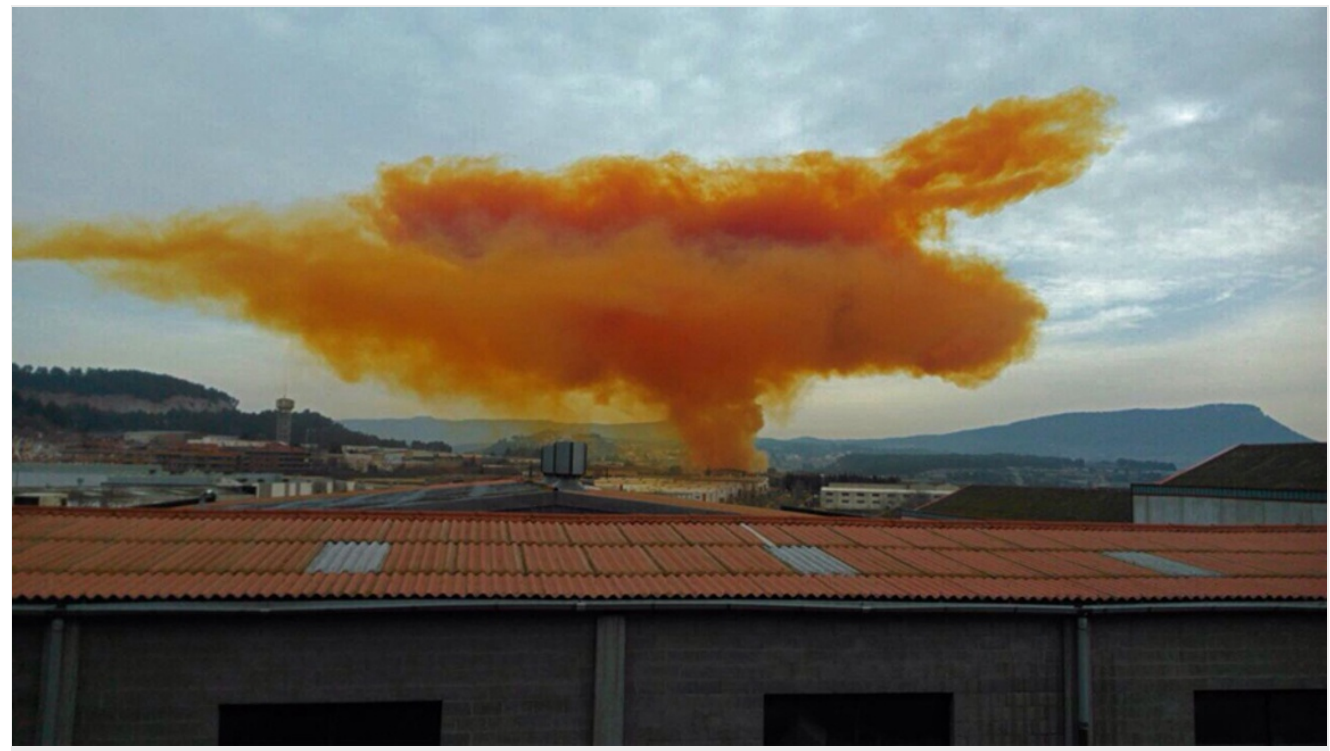

Ramon Costa/Demotix/Corbis

Three people were injured when a chemicals factory in lgualada, Spain, exploded this month. A brightly coloured cloud formed above the site, and residents in nearby towns were told to stay indoors until the toxic miasma dispersed, which took several hours.

\section{Shedding light on the dark side}


The Moon's invisible face

The side of the Moon that cannot be seen from Earth is documented in this NASA video, constructed by the space agency's Scientific Visualization Studio from data collected by the Lunar Reconnaissance Orbiter.

\section{Zombie ant close-up}

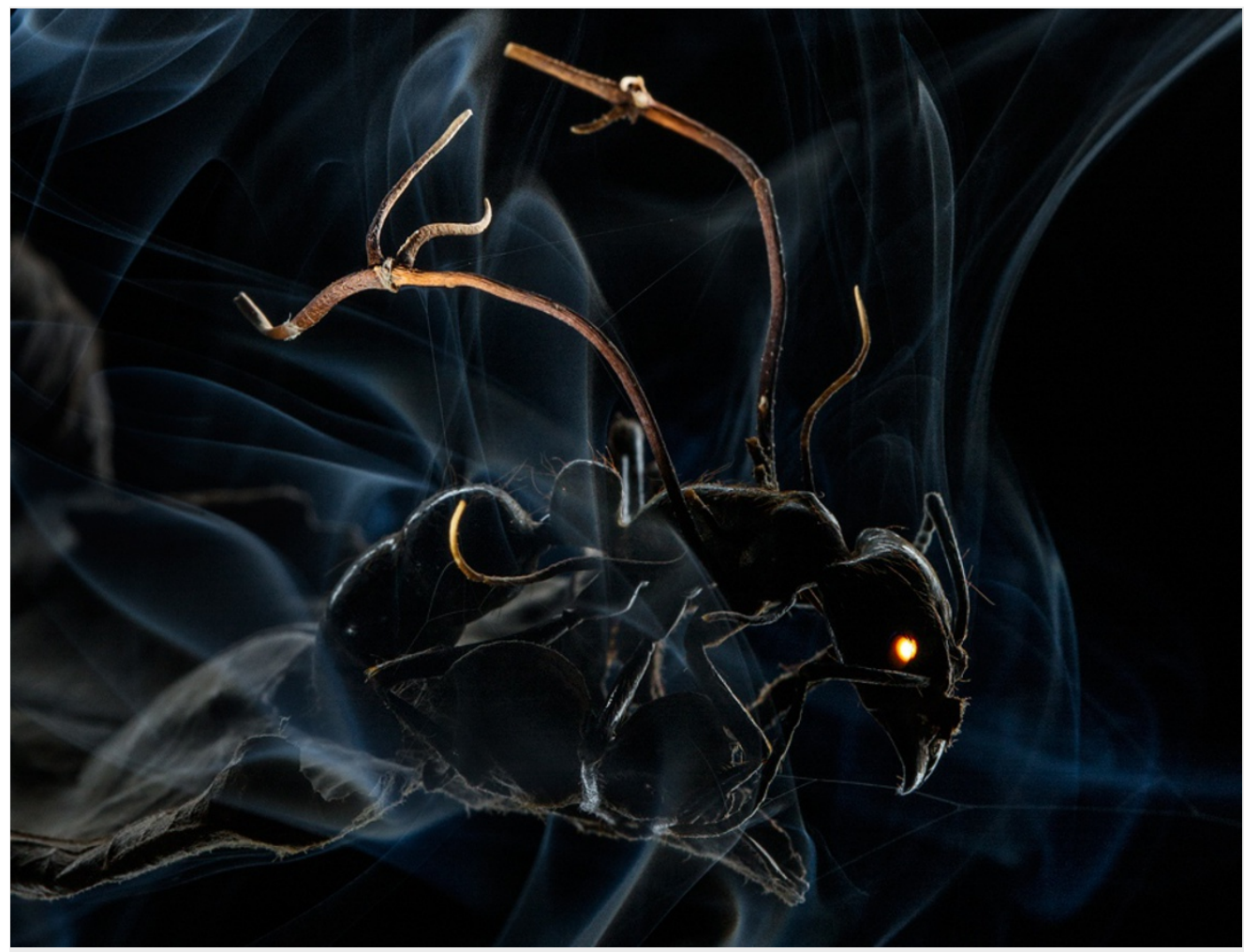

Anand Varma/National Geographic/worldpressphoto.org/awards/2015

The fungus Ophiocordyceps hijacks unsuspecting ants, forcing them to leave their nests and climb, zombie-like, into trees, where they die. The fungus then grows out of their bodies and rains down spores onto other ants. This image of the horrific process is part of a series of pictures on parasite mind control that won Anand Varma first prize in the nature-stories category of the World Press Photo 2015 contest.

\section{No pictures!}




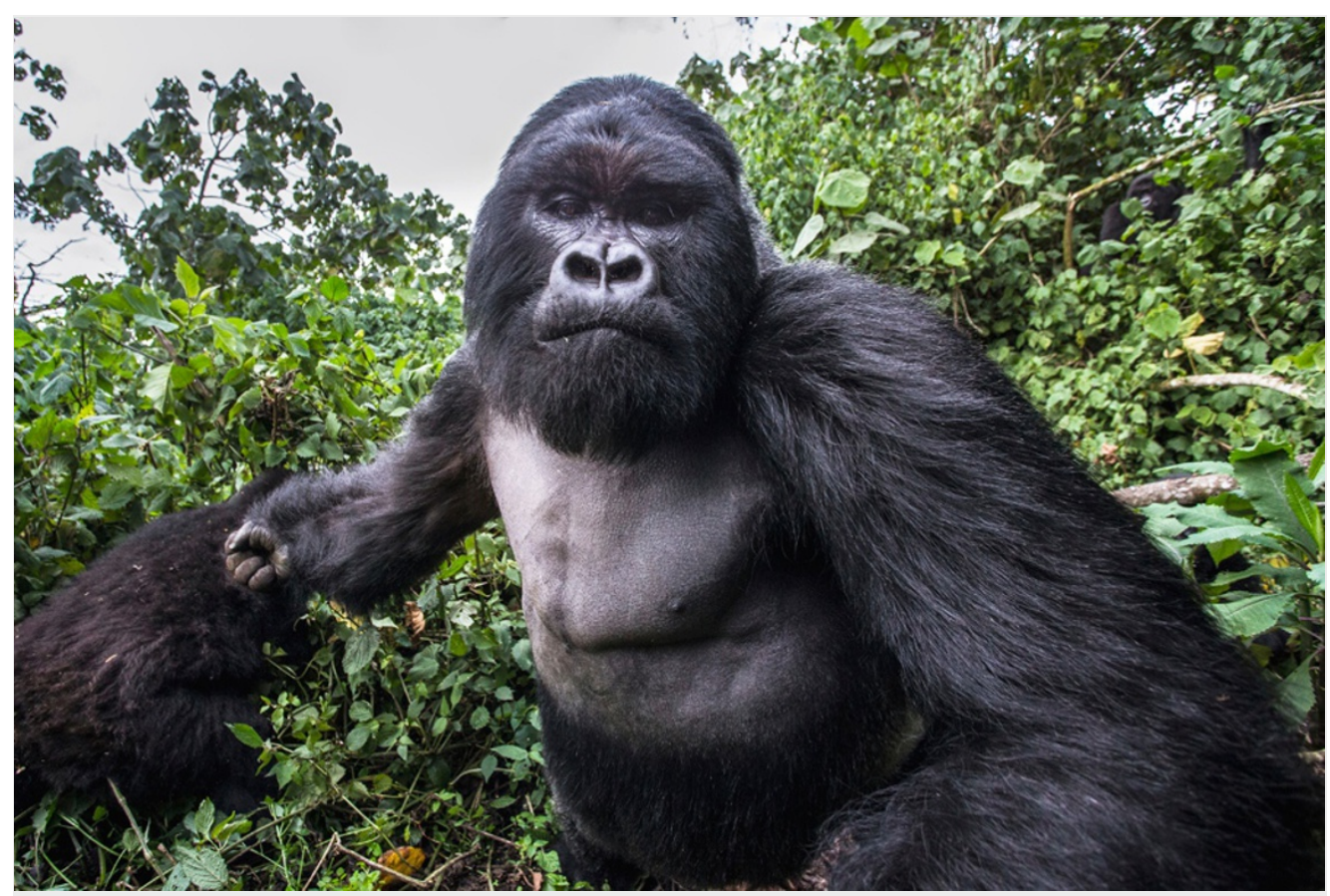

Christophe Courteau/Caters News Agency

This gorilla took offence at wildlife photographer Christophe Courteau trying to snap him in the Volcanoes National Park in Rwanda. Such rambunctious behaviour is probably due to the animal, called Akarevuro, having a stomach full of fermenting bamboo stems — in effect getting drunk.

\section{The world at night}

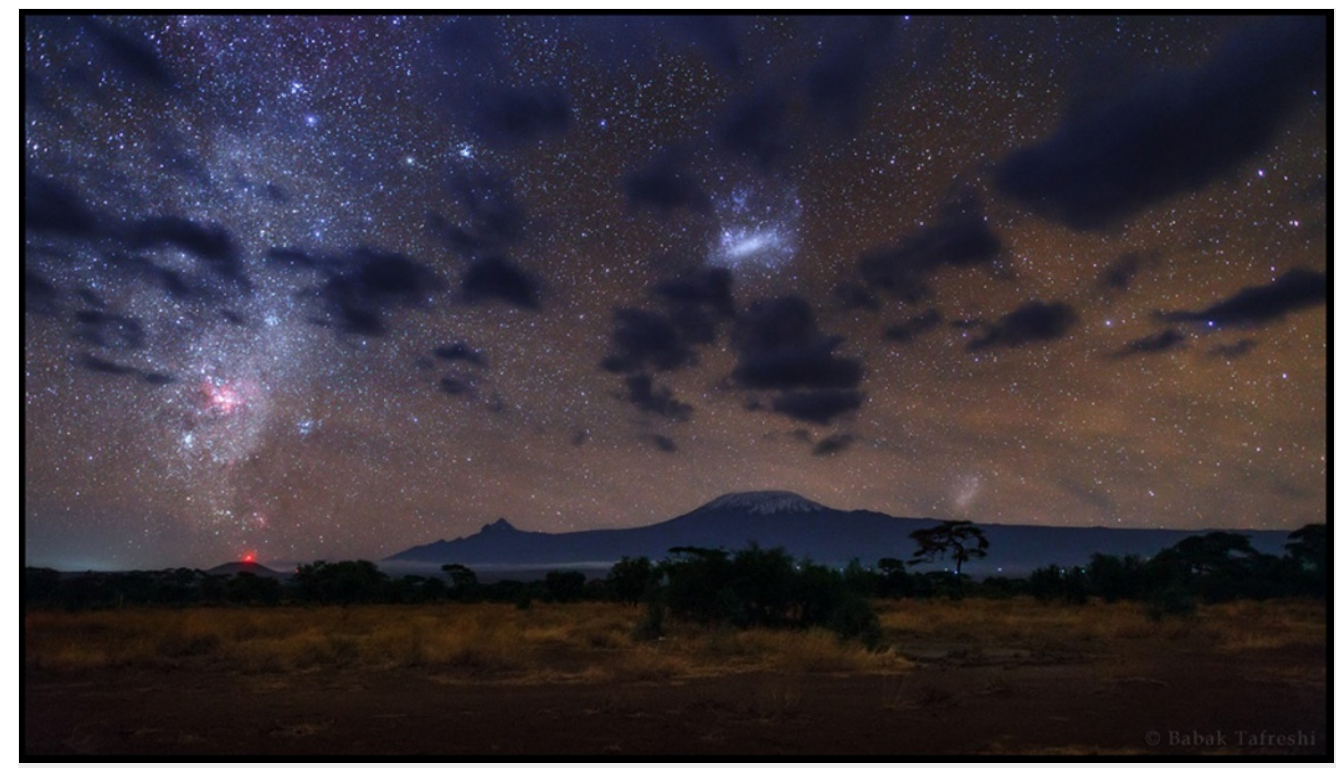

Babak Tafreshi/TWAN; twanight.org/tafreshi

Photographer Babak Tafreshi took this image of the night sky above Mount Kilimanjaro in Tanzania. The Milky Way, with the Carina Nebula (the red cloud), and the Magellanic Clouds, a duo of dwarf galaxies, are visible.

\section{Fantastical anglerfish}



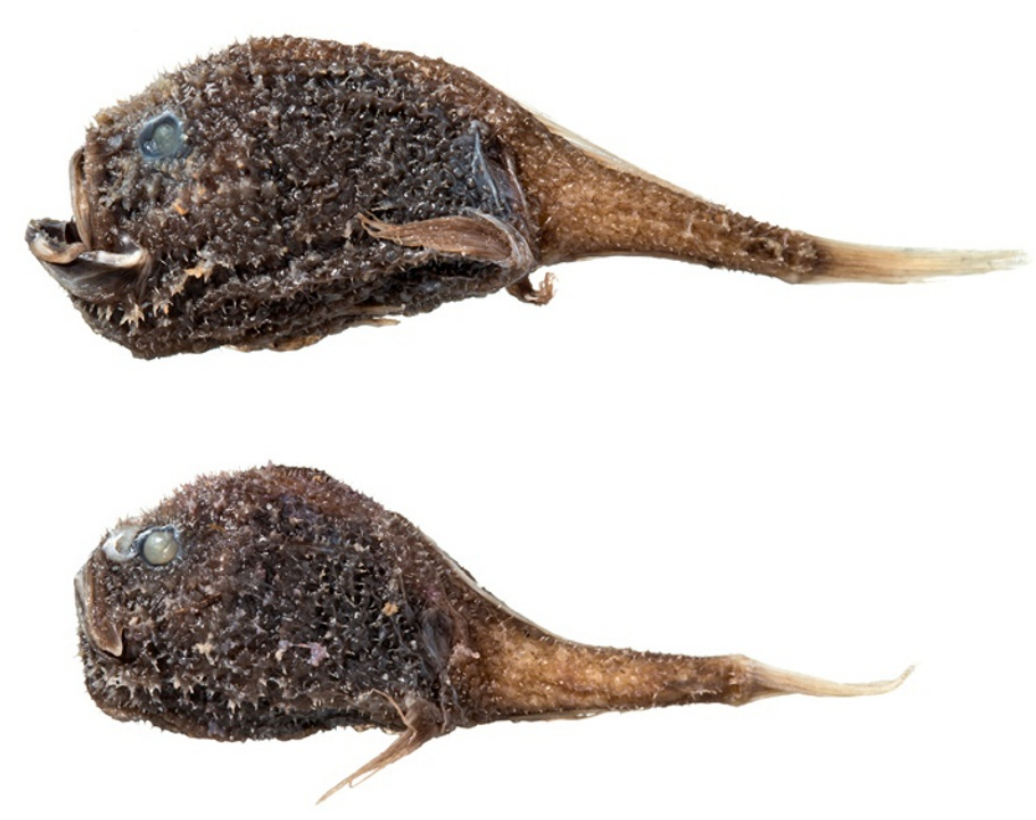

Carl Bento/Australian Museum

This little critter is a Chaunacops melanostomus anglerfish, also known as the tadpole coffinfish, the first undenwater observations of which were reported last month in the Joumal of Fish Biology. In a bonus for deep-sea anglerfish fans, the paper also reports an entirely new species, Chaunacops spinosus, or eastern tadpole coffinfish.

Nature | doi:10.1038/nature.2015.17018

\section{Corrections}

Corrected:An earlier version of this story mis-identified the Brown-backed solitaire (Myadestes occidentalis). The text has been corrected. 